\title{
Advanced Process Control Application and Optimization in Industrial Facilities
}

DOI: $10.15255 / \mathrm{KUI} .2014 .010$

KUI-5/2015

Professional paper

Received March 5, 2014

Accepted November 12, 2014

\author{
S. Howes, ${ }^{a}$ I. Mohler, ${ }^{*}$ and N. Bolf ${ }^{b}$ \\ a PiControl Solutions, Houston, TX, USA \\ ${ }^{\mathrm{b}}$ Faculty of Chemical Engineering and Technology, University of Zagreb \\ Savska c. 16/5a, 10000 Zagreb, Croatia
}

\begin{abstract}
$\|$ Abstract
This paper describes application of the new method and tool for system identification and PID tuning/advanced process control (APC) optimization using the new 3G (geometric, gradient, gravity) optimization method. It helps to design and implement control schemes directly inside the distributed control system (DCS) or programmable logic controller (PLC). Also, the algorithm helps to identify process dynamics in closed-loop mode, optimizes controller parameters, and helps to develop adaptive control and model-based control (MBC). Application of the new 3G algorithm for designing and implementing APC schemes is presented. Optimization of primary and advanced control schemes stabilizes the process and allows the plant to run closer to process, equipment and economic constraints. This increases production rates, minimizes operating costs and improves product quality.
\end{abstract}

$\|$ Keywords

System identification, controller tuning and optimization, advanced process control, model based control

\section{Introduction}

Application of advanced control methods has rapidly increased since the 1990s in the chemical, petrochemical, and oil refining industry. The terms DCS, PLC and PID can be found in many articles like: Henriquez et al., ${ }^{1}$ Van Schuppen et al., ${ }^{2}$ Cauffriez et al., ${ }^{3}$ Campelo et al., ${ }^{4}$ Rullán, ${ }^{5}$ Valencia-Palomo et al., ${ }^{6}$ Bolton, ${ }^{7}$ Reznik et al., ${ }^{8}$ Panda, ${ }^{9}$ and Escobar et al. ${ }^{10}$

Also, the terms APC, model predictive control (MPC) and $M B C$ are mentioned many times in literature as in: Lababidi et al., ${ }^{11}$ Dobos et al., ${ }^{12}$ Zhi Gao et al., ${ }^{13}$ Willersrud et al., ${ }^{14} \mathrm{Al}$-Gherwi et al., ${ }^{15}$ Peng et al., ${ }^{16}$ and Malchow et al. ${ }^{17}$

As can be seen, these terms are ubiquitous in chemical process control literature. A prerequisite for APC/MPC success is a well-designed primary PID control platform with optimized parameters. Increasing application of APC schemes places higher demands on the skills and experience level of process control engineers and technicians in the control rooms.

This paper nicely explains the application of the powerful 3G optimization method, ${ }^{18-20}$ which helps the control engineer and technician to design and implement control schemes inside the DCS, optimize the controller performance and increase the plant's profit because of improved plant operation.

Application of process control software tools for system

*Corresponding author: Ivan Mohler

e-mail: imohler@fkit.hr identification, PID tuning optimization and APC calculations is still not too common in the control room environment in manufacturing plants. The reasons for this is that most current software tools and dedicated optimization algorithms are too complex, rather expensive, and neither robust nor practical for the control room environment.

Further, applications of the newly developed 3G algorithm are illustrated. It can accurately identify process models admist the presence of large unmeasured disturbances or oscillations and high noise from the data, all in complete closed-loop mode without conducting any additional new step-tests in the plant. Current system identification and optimization algorithms such as: autoregressive-moving-average model with exogenous inputs (ARMAX), step response coefficient models, Box and Jenkins, etc., are rather sensitive to the presence of noise, disturbances and drifts in the data.

In the PID and APC parameter optimization area, the application of internal model control (IMC), Lambda tuning, Ziegler-Nichols, Cohen Coon, and other methods, still produces conservative and not optimal control action. The 3G algorithm can accurately calculate PID/APC parameters for the processes where currently known heuristic-based methods have failed.

\section{Process control application hierarchy}

Fig. 1 shows the common industrial process control hierarchy split into three major categories. At the lowest level are the primary control loops - mostly PID controllers for con- 
trolling flow-rates, pressures, levels, temperatures and other variables in the industrial plant. To handle slow process dynamics, multivariable interactions, long dead times and complex control loops, pure PIDs alone cannot effectively provide the best control quality, and APC applications are necessary. Further, to incorporate market, economic conditions, process and equipment constraints and nonlinearities, a third application level - real time optimization, can further provide monetary benefits.

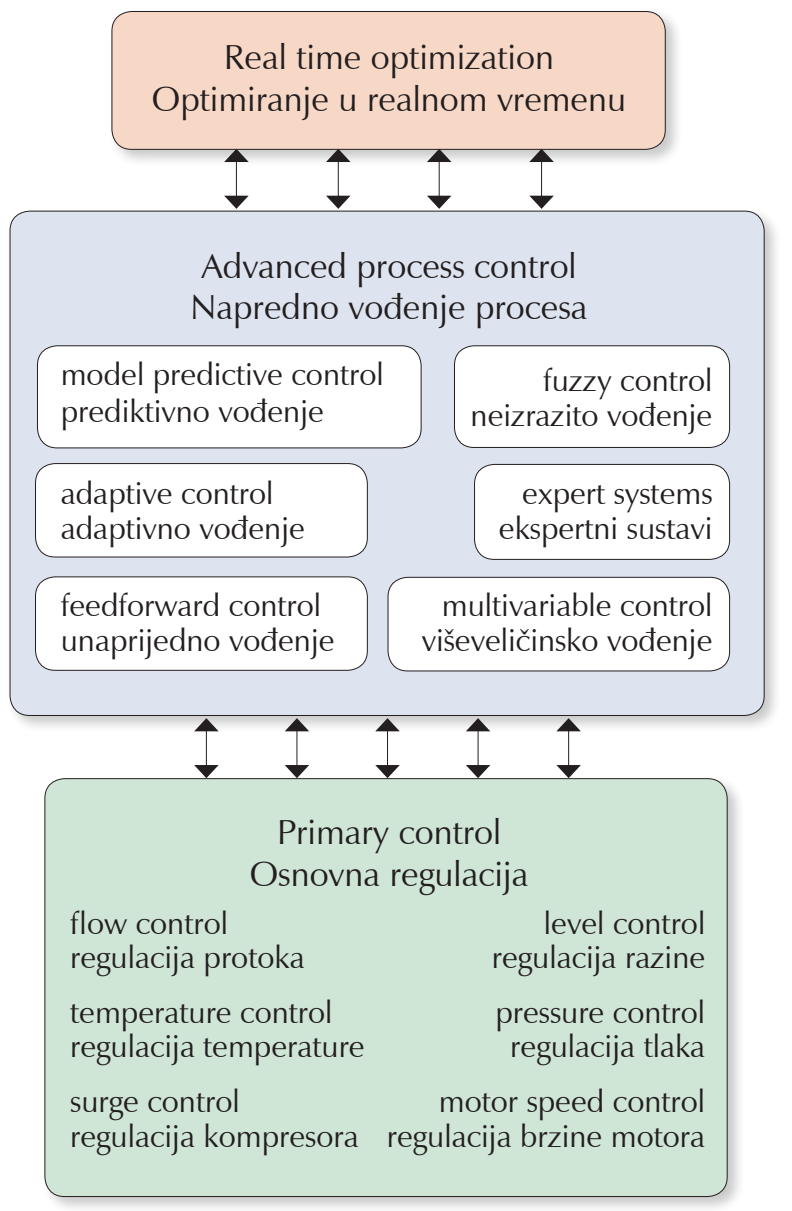

Fig. 1 - Process control hierarchy

Slika 1 - Hijerarhija vođenja procesa

Primary control and DCS-based APC, if correctly implemented, can significantly increase the plant's profit margins. Optimized primary and advanced control stabilizes process operation and pushes the operation closer to process, equipment and economic constraints. This increases production rates, minimizes operating costs and improves product quality. ${ }^{21}$

\section{Challenges and opportunities in modern control rooms}

The increasing use of primary and advanced control poses the following challenges in the control rooms:

1. New control and process engineers and DCS or PLC technicians come into the plant on a regular basis. They need to be trained in practical primary and advanced process control.

2. Many DCS-based APC concepts cannot be taught practically at schools and colleges. Learning practical process control skills quickly is not easy and simple.

3. Changes in process or operating conditions, complexity, nonlinearities, external unmeasured disturbances, high signal noises can impact closed-loop control quality resulting in inefficient operation including lost production, and could even cause equipment shutdowns and safety/reliability incidents.

4. Constant software and hardware upgrades add to the maintenance challenges in the control room.

Using modern DCS and/or PLCs, various powerful, robust, money-making control schemes can be implemented. This paper also describes the following powerful techniques for designing and implementing DCS or PLC-based APC schemes, which are optimized using the $3 \mathrm{G}$ algorithm:

1. Process dynamics identification,

2. Primary PID and APC parameters optimization,

3. Online adaptive control,

4. Model-based control for product quality and production rate maximization.

\section{Process dynamics identification}

Process measurement ranges can be from as fast as milliseconds on compressor surge control and motor control to as low as many hours in tall super-fractionator distillation columns. In modern control rooms, there are plenty of data sets available containing the controller output (OP), process variable (PV) and set point (SP). Data may contain OP step changes with the controller in manual mode, or may contain SP changes in auto mode. There are many opportunities in the plant where the operator may have made changes to the SP or OP. All these data sets are abundantly available from the plants data historians that continuously archive the data.

From collected data it is possible to identify process $d y$ namics i.e. the dynamic relationship between the controlled variable $(\mathrm{CV})$ and manipulated variable $(\mathrm{MV})$ for each control loop. Most chemical processes can be characterized by one of the common industrial process models (zero, first or second order). ${ }^{22,23}$

Pitops $^{24}$ identification and optimization software tool was used to identify the model parameters using existing data of distillation column pressure controller from an olefins plant, which were stored in the plant's data historian. Fig. 2 shows pressure control (PC) data when the loop was in manual mode. The PC's output (OP), i.e. the valve position, was moved a few times which caused the pressure PV to respond. Identified first order process model parameters are shown on the right top side of the Figure: Time delay $=1.3 \mathrm{~min}$; Process gain $=-1.017 \mathrm{bar} / \%$; Time constant $=5.4 \mathrm{~min}$. 
Time delay $=1.3 \mathrm{~min}$

Process gain $=-1.017 \mathrm{bar} / \%$

Time constant $=5.4 \mathrm{~min}$
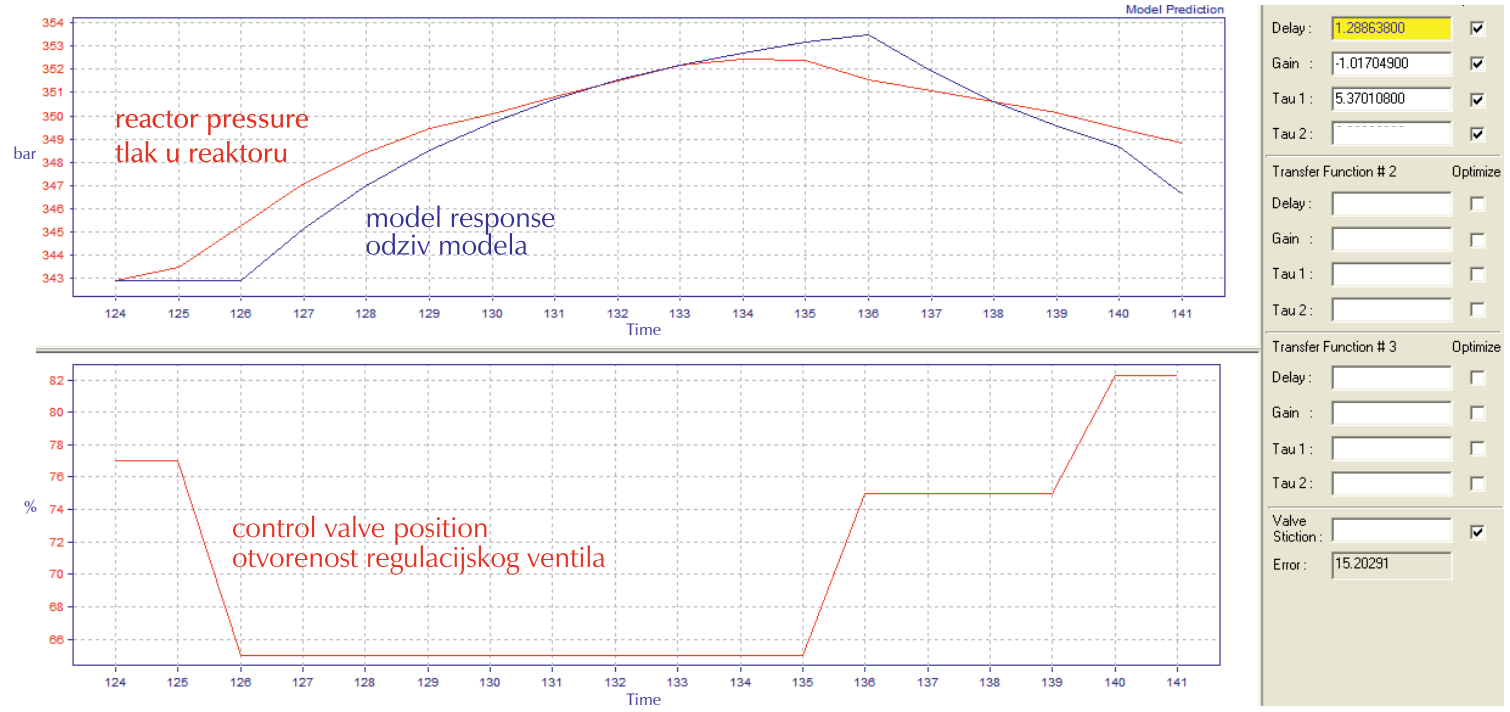

Fig. 2 - Pressure control loop model identification ${ }^{24}$

Slika 2 - Identificiranje modela regulacijskog kruga tlaka ${ }^{24}$

Time delay $=9.0 \mathrm{~min}$

Process gain $=-0.091 \% /\left(\% \mathrm{~min}^{-1}\right)$
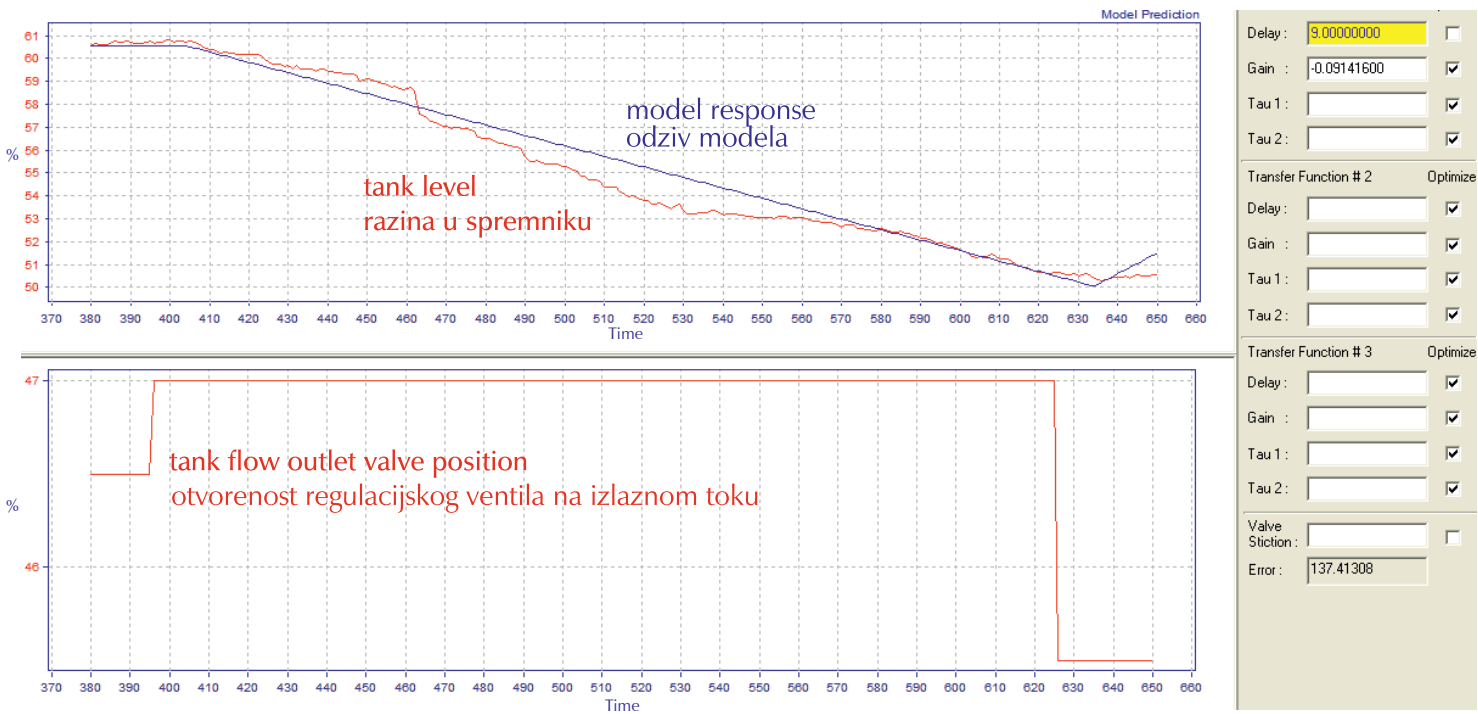

Fig. 3 - Level control loop model identification

Slika 3 - Identificiranje modela regulacijskog kruga razine

The blue trend in the top window shows the model prediction which follows the red trend of the actual column pressure data in the top window and the bottom trend is the control valve position.

The next example shows data on a tank level controller (LC) from an oil refinery - crude distillation plant section, as shown in Fig. 3. The LC's output (valve position) was moved a few times (bottom window) which caused the level PV to respond (red trend in top win- dow). The 3G algorithm identifies the zero order (ramp or integrator) model parameters all in the time domain, as shown on the right side of the Figure: Time delay = $9.0 \mathrm{~min}$; Process gain $=-0.091 \% /\left(\% \mathrm{~min}^{-1}\right)$.

Fig. 4 shows standard process step test data collected from data historian on the previous level control example. In this example, the open-loop data (controller in manual mode) is used. On the right side of the Figure, mismatch between the model and process variable is visible. This could appear 

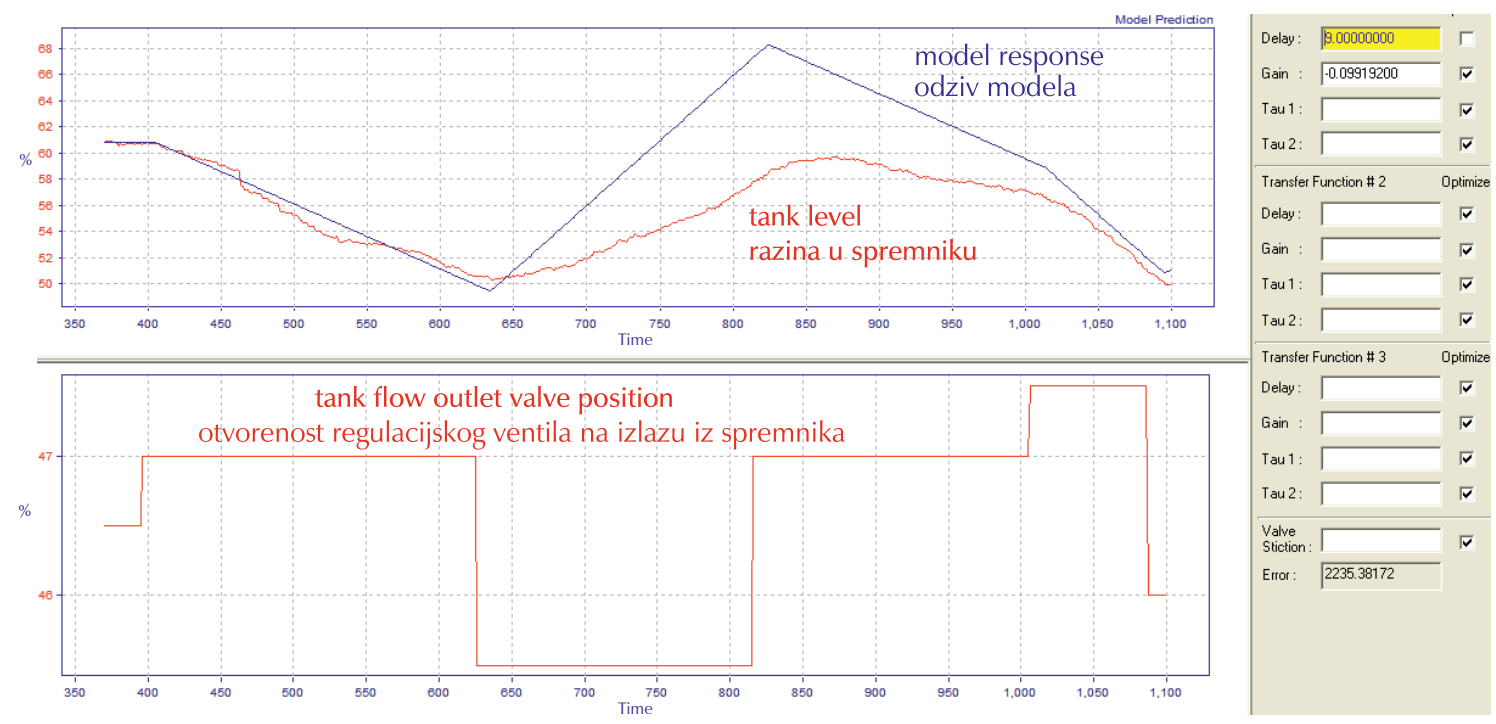

Fig. 4 - Level control loop model identification

Slika 4 - Identificiranje modela regulacijskog kruga razine
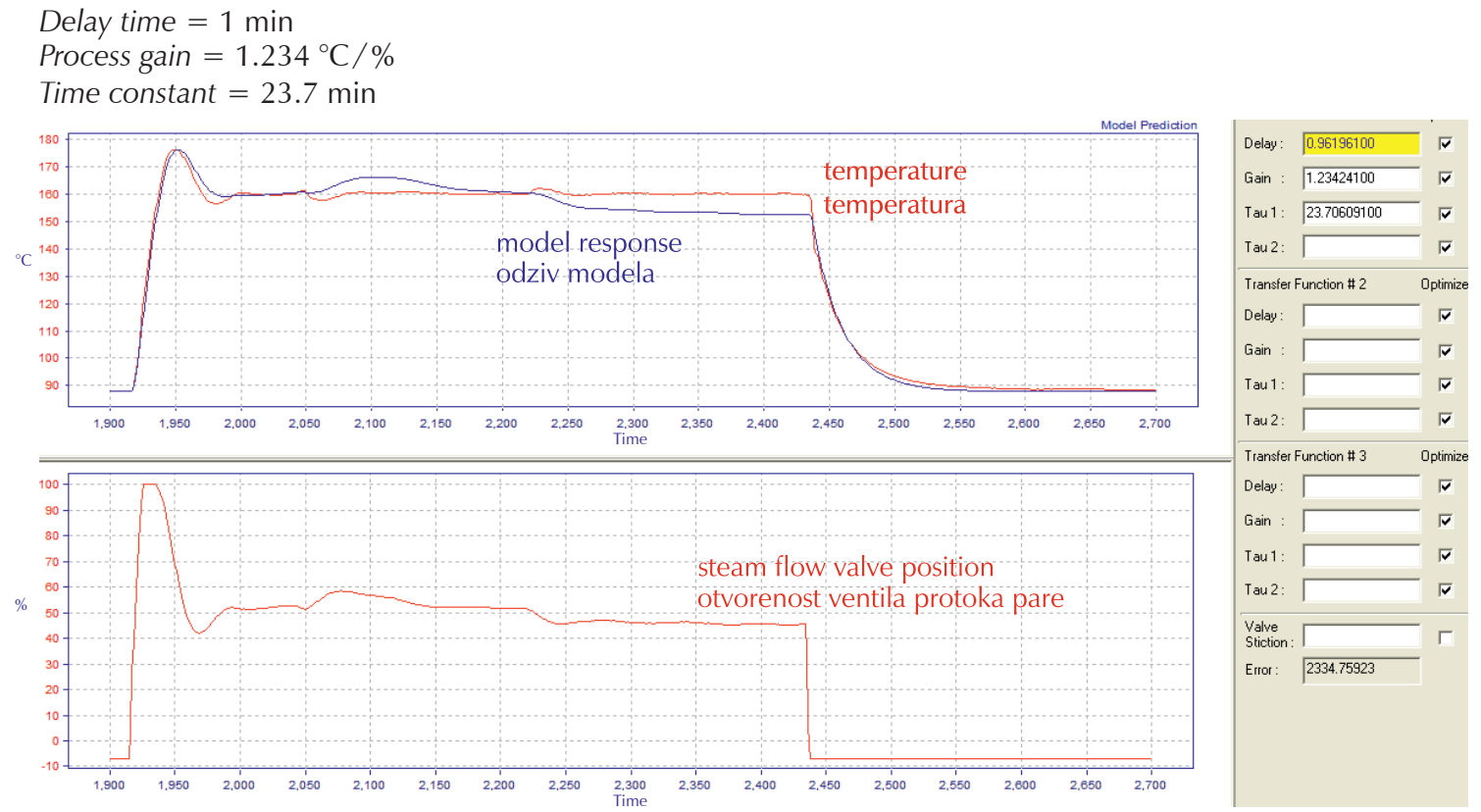

Fig. 5 - Temperature control loop model identification - closed loop mode Slika 5 - Identificiranje modela zatvorenog regulacijskog kruga temperature

because of valve stiction, flow meter problems or unmeasured disturbances that could mask the effect of the control valve step tests. Using the 3G identification algorithm, it is also possible to determine control valve stiction based on the OP and PV data.

The next example shows model parameter identification using closed-loop data (controller in auto mode), as shown in Fig. 5. This example involves a temperature controller which is manipulated by a steam flow controller in a distillation batch process. The TC output is often zero (there is no steam flow). When the process is ready for increasing the temperature, a batch sequence logic tag changes the
TC's set point. Optimal tuning of the TC was demanding because the TC is not always in control during the day shift. Using temperature PV and steam flow-rate SP data in a closed-loop control, the first order model was identified. The identified process parameters are: Delay time $=1 \mathrm{~min}$; Process gain $=1.234{ }^{\circ} \mathrm{C} / \%$; Time constant $=$ $23.7 \mathrm{~min}$.

The last example shows a multivariable model-predictive controller from a chemical plant manufacturing catalyst in closed-loop mode, simultaneously manipulating three MVs: distillation column feed, side product flow-rate and reflux flow-rate, as shown in Fig. 6 . The product impurity 

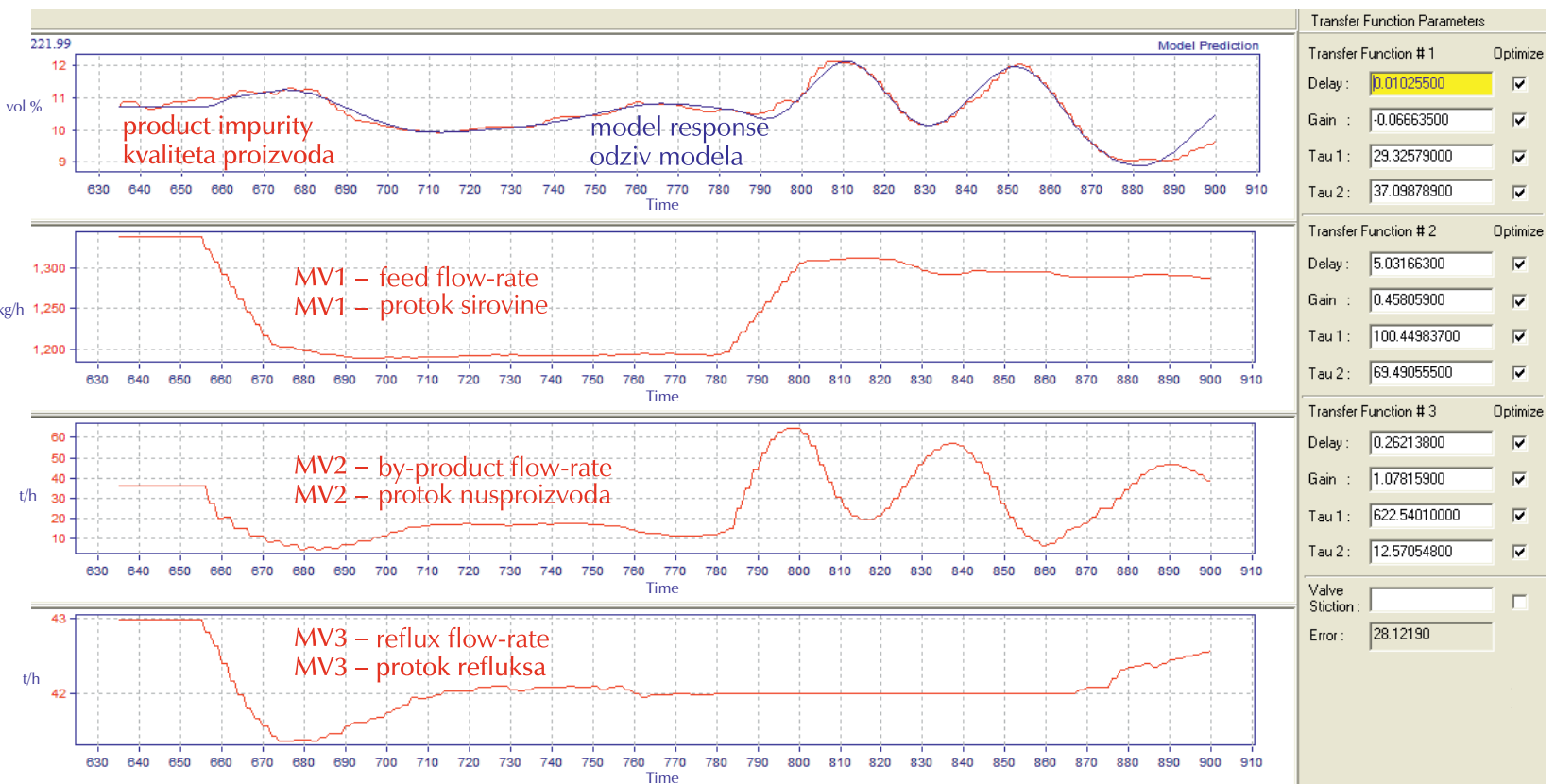

Fig. 6 - Multivariable control loop model identification - closed loop mode

Slika 6 - Identificiranje viševeličinskog modela zatvorenog regulacijskog kruga

is impacted by all three MVs (red trend in the top window). All three second-order models are identified simultaneously using the data from the closed-loop mode.

This identification can be used to improve the step response coefficient or any other kind of models used in the commercially multivariable model-predictive controllers in order to improve the controller performance.

\section{PID controller tuning and optimization}

Knowing the process model helps to optimally tune base-level and cascade/advanced controllers. Fig. 7 shows an industrial pressure control (PC) example, which is the same as in Fig. 2. The bottom window shows the PC's output. The top window shows the SP (blue trend) and PV (red trend).

The PC's objective is to not only provide crisp SP control but also to respond aggressively when hit by a disturbance. Disturbances can come and go anytime and it is important for the PC to respond quickly by closing or opening the valve immediately. The key is that such aggressive control action needed during disturbance rejection should not result in sustained oscillations at steady state.

The 3G optimization algorithm generates such tuning parameters that give crisp, non-oscillatory SP control while responding quickly during fast and large disturbances. This resulted in increasing the controller proportional gain from 2 to 11 in one step and the integral from 8 to 3 minutes.

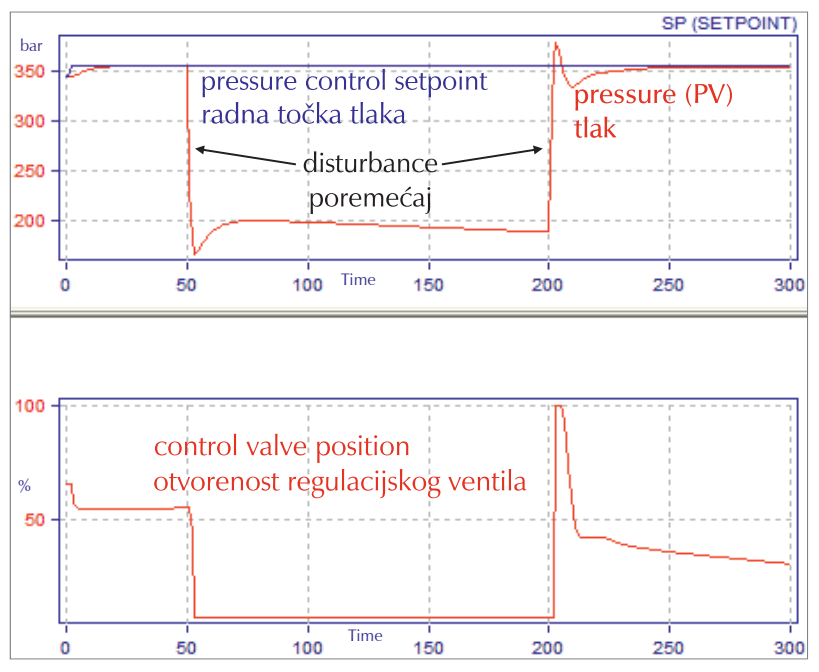

Fig. 7 -Optimized pressure controller in presence of disturbance

Slika 7 - Odziv optimiranog regulatora tlaka pri pojavi poremećaja

Without modern optimization tools that use the 3G optimization algorithm, control engineers confronted with tuning such a PC would not have the confidence to increase the controller gain drastically from 2 to 11 in one step. They would have crept up the gain from 2 to 2.5 and 3 etc., over a much longer time period. And since the disturbance does not come all the time, it is hard to manually tune the loop for optimal control without the help of modern tools. 


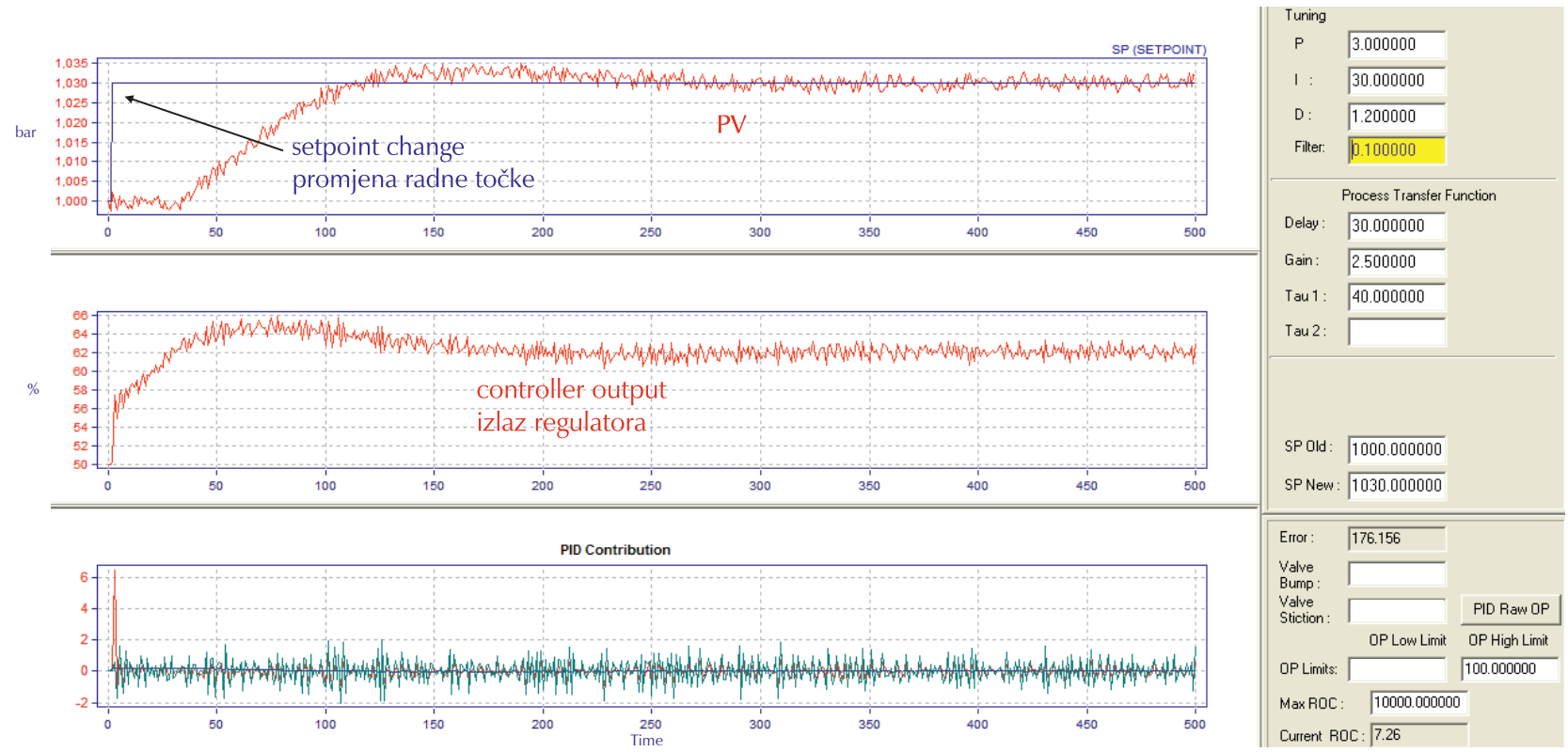

Fig. 8 - Optimized PID controller in presence of SP change and high noise

Slika 8 - Odziv optimiranog PID regulatora pri promjeni radne točke i velikom šumu u signalu

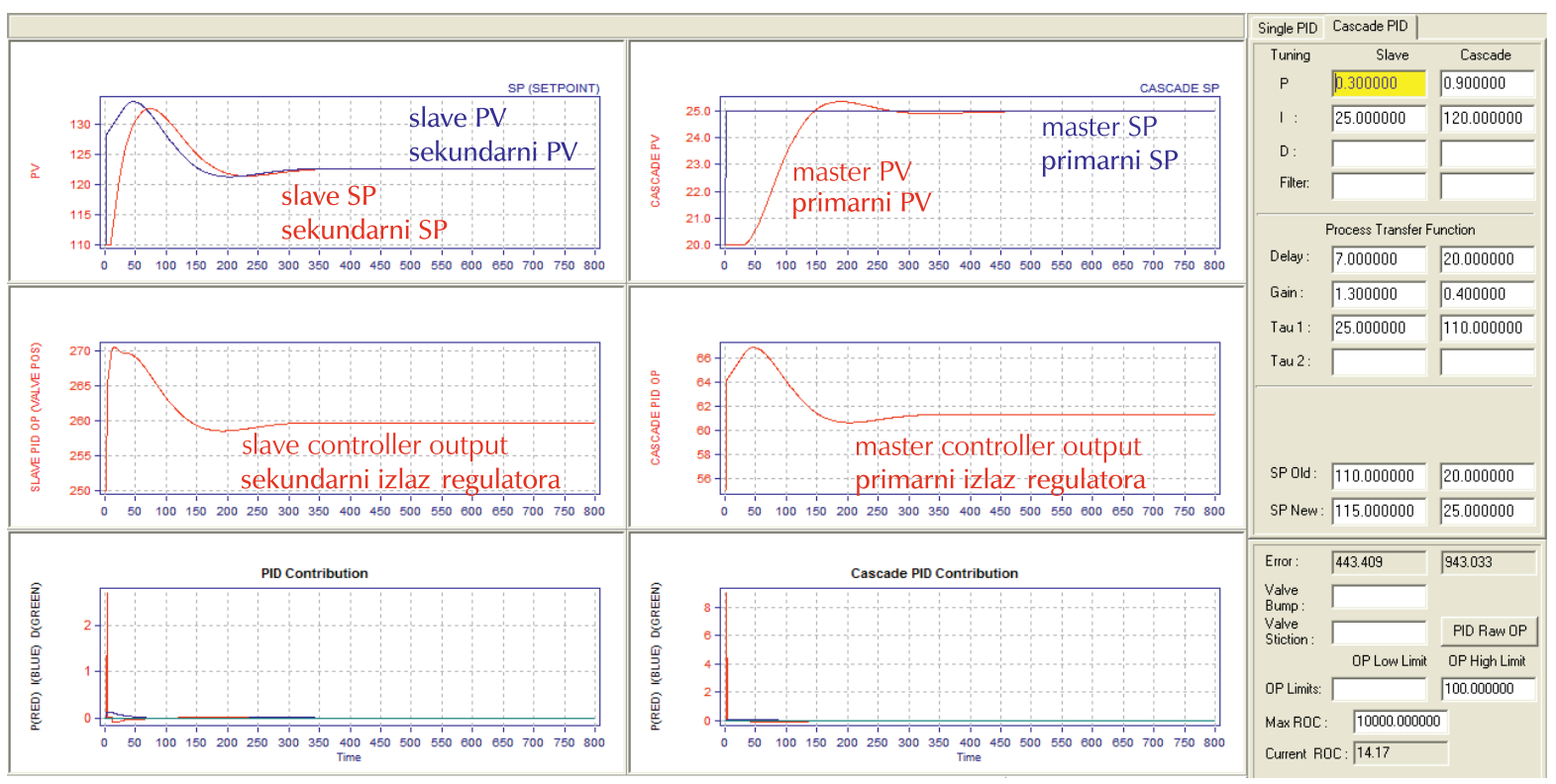

Fig. 9 - Optimized cascade controllers in presence of SP change

Slika 9 - Odzivi optimirane kaskadne regulacije pri promjeni radne točke

The second example shows an illustrative simulation of how the PID controller parameters are optimized in the presence of high signal noise, as shown in Fig. 8. The real process is mimicked by simulating the same level and frequency of white signal noise seen in the real process and optimal PID controller parameters are calculated with the 3G algorithm.

The following text explains the optimization of the cascade control which is common in all chemical processes. Cascade controllers can be fast as in PC to FC chains or slow as in AC to TC or TC to TC cascades controlling product stream quality measured by on-line analysis or tempera- ture inferential controllers. The optimizer can identify both slave and cascade process dynamics and then optimizes cascade PID parameters. Fig. 9 shows an example of a master AC and its slave TC from the simulator, which mimics a distillation column cascade example.

One of the most powerful schemes to maximize plant profits is implementing production rate maximizer schemes in the DCS or PLC, as illustrated in Fig. 10. As many as ten or more constraints can be implemented as part of the constraint pusher schemes. The optimizer can identify the process dynamics for all the constraints and then precisely optimize all the tuning parameters. 


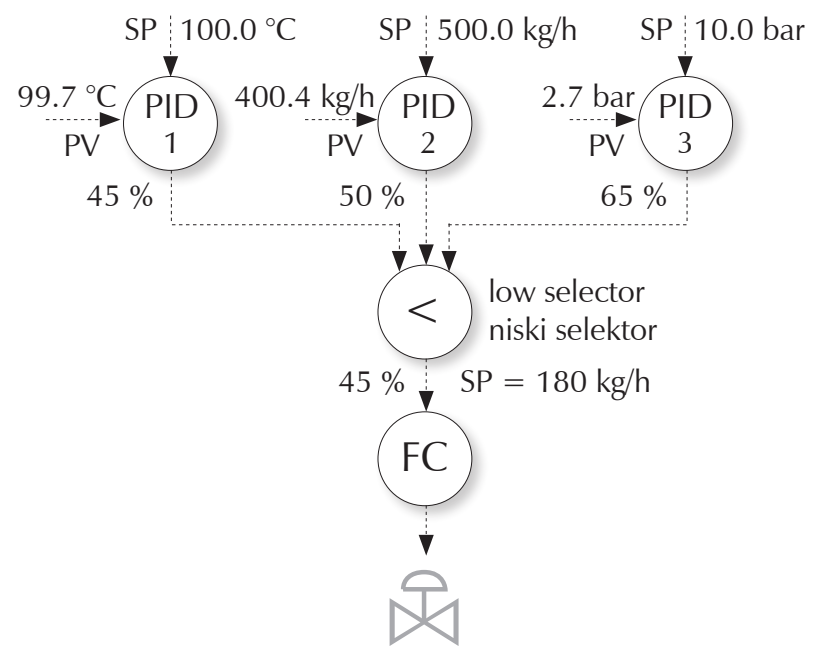

Fig. 10 - Production rate maximizer controllers Slika 10 - Regulacija za maksimiziranje proizvodnje

\section{Feedforward and model-based control}

In all chemical processes, control quality can be significantly improved on various important control schemes using feedforward control. Unfortunately, almost all feedforward tuning parameters are estimated today in the control room by trial-and-error or "best-guessed" estimates.

The 3G algorithm provides powerful functionality to mathematically identify the feedforward parameters: lead, lag, gain and dead time. Understanding how feedforwards work allows building custom new applications all inside in the DCS or PLC for numerous other innovative purposes. Fig. 11 shows a pulse signal input to a feedforward model with the lead constant less than the lag constant from the simulator.

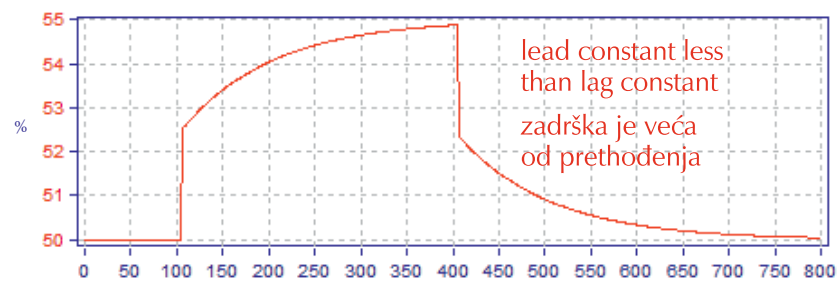

Fig. 11 - Controller output in the case of higher lag in the feedforward control

Slika 11 - Djelovanje regulatora u slučaju veće zadrške u unaprijednoj regulaciji

Fig. 12 shows a pulse signal input to a feedforward model with the lead constant higher than the lag constant. Notice the differences in the response in the two cases. When lead is higher than lag, there is an initial strong kick (rise) whose magnitude is higher even than the total maximum change at steady state. This case is common when the main process dynamics are slower than the disturbance dynamics.

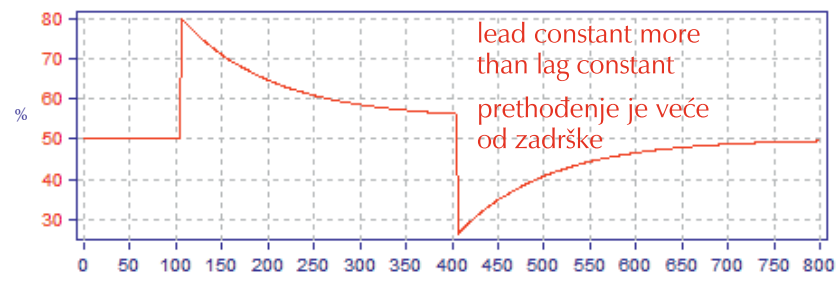

Fig. 12 - Controller output in the case of higher lead in the feedforward control

Slika 12 - Djelovanje regulatora u slučaju većeg prethođenja u unaprijednoj regulaciji

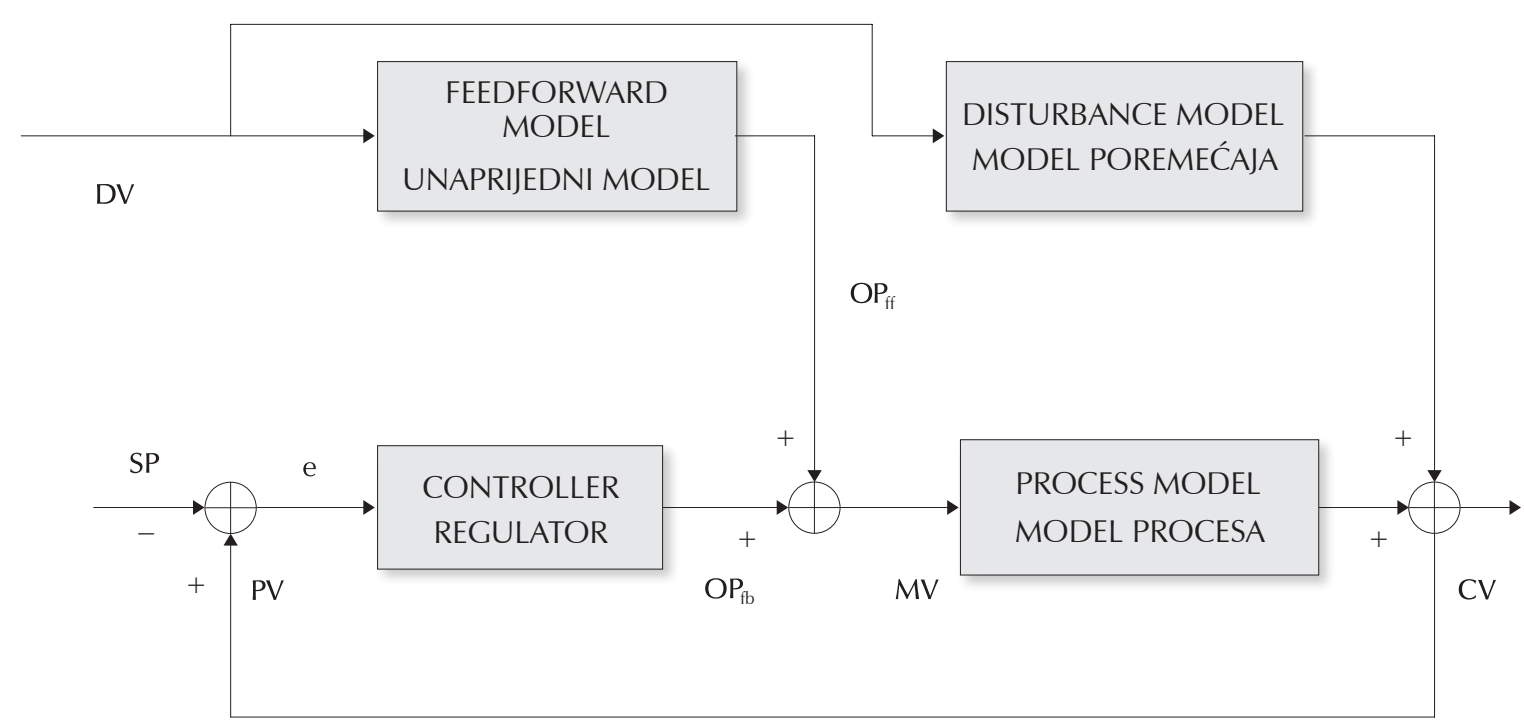

Fig. 13 - Feedforward control simulation and optimization scheme

Slika 13 - Prikaz simuliranja i optimiranja unaprijedne regulacije 


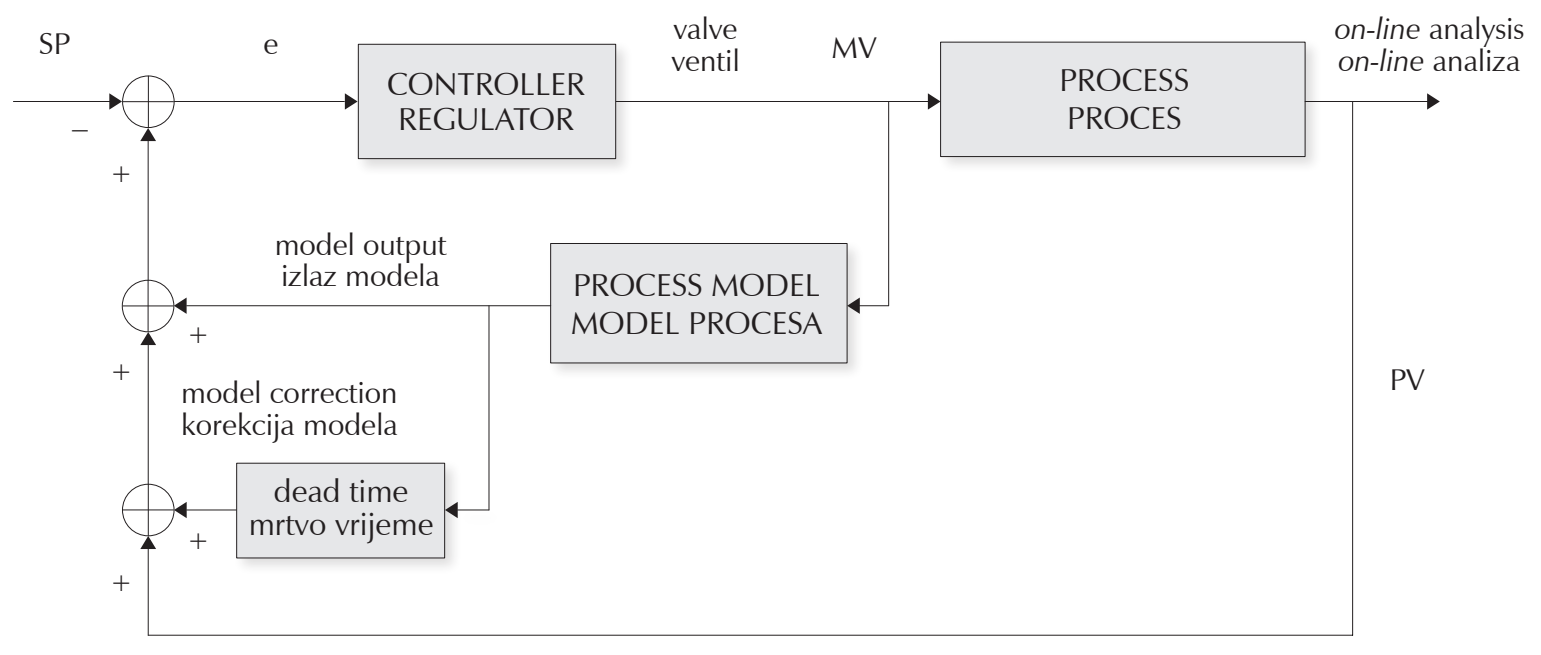

Fig. 14 - Model-based control scheme for dead-time compensation

Slika 14 - Prikaz vođenja temeljenog na modelu procesa za kompenzaciju mrtvog vremena

By mastering the quantitative details of how feedforwards work, an engineer, operator or technician can easily build powerful feedforward control schemes inside the DCS or PLC with numerous benefits. Fig. 13 shows a sample calculation overview of a feedforward control scheme using the $3 \mathrm{G}$ algorithm.

Another great opportunity is the implementation of model-based controllers in the DCS or PLC. Any model based on rigorous, empirical, semi-empirical or regressed models can be implemented in the DCS using once through or iterative calculations. Such models can be used to implement closed-loop controllers in the DCS or PLC. Furthermore, measurement feedback such as from online gas chromatographs or laboratory analysis can be incorporated into the predictive models. This model-based controller design with predictive, corrective and feedback closed-loop control action can also be nicely built using the new 3G optimization algorithm. Model-based structure is shown in Fig. 14.

\section{Conclusion}

Application of the newly developed identification and optimization 3G algorithm is presented. It can be implemented in the DCS or PLC with increased recurring average annual profits ranging from 50000 to 3 million dollars, depending on the size and type of the plant. Using the $3 \mathrm{G}$ algorithm, it is possible to identify process dynamics in the presence of disturbances and noise, design primary and advanced process control schemes, and optimize their PID/APC parameters. The ability to identify system dynamics using this $3 \mathrm{G}$ approach allows successful identification using ultra-short duration data amidst disturbances and allows optimization of PID tuning and APC implementation inside an existing DCS or PLC in a remarkably short duration, at a lower cost and higher accuracy.

\section{List of abbreviations Popis kratica}

3G - geometric, gradient, and gravity method

- geometrijska, gradijentna i gravitacijska metoda

AC - analyzer controller

- regulator sastava

APC - advanced process control

- napredno vođenje procesa

ARMAX - autoregressive-moving-average model with exogenous inputs

- model autoregresivnog pomičnog prosjeka s egzogenim ulazima

CV - controlled variable

- vođena varijabla

DCS - distributed control system

- distribuirani sustav za vođenje

DV - disturbance

- poremećaj

FC - flow controller

- regulator protoka

FF $\quad-$ feedforward signal

- unaprijedni signal

IMC - internal model control

- vođenje internim modelom

LC - level controller

- regulator razine

MBC - model-based control

- vođenje temeljeno na modelu

MPC - model predictive control

- prediktivno vođenje

MV - manipulated variable

- upravljana varijabla

OP - output

- izlaz 


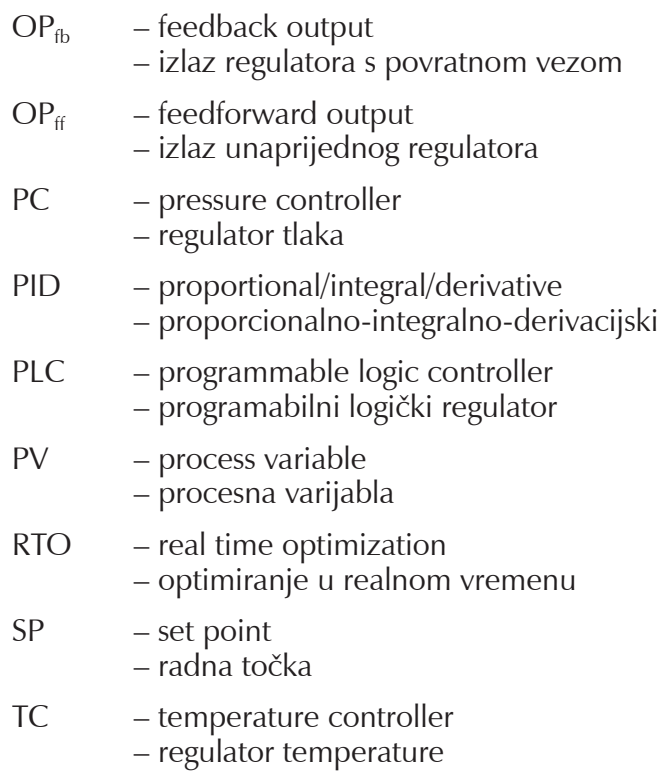

\section{References \\ Literatura}

1. H. R. Henríquez, C. Cuevas, M. Rabelo, A. Caicedo, Stabilization of Distributed Control Systems with Delay, Syst. Control. Lett. 60 (2011) 675-682, doi: http://dx.doi.org/10.1016/j. sysconle.2011.04.012.

2. J. H. van Schuppen, O. Boutin, P. L. Kempker, J. Komenda, T. Masopust, N. Pambakian, A. C. M. Ran, Control of Distributed Systems: Tutorial and Overview, Eur. J. Control. 17 (5-6) (2011) 579-602, doi: http://dx.doi.org/10.3166/ejc.17.579602.

3. L. Cauffriez, J. Ciccotelli, B. Conrard, M. Bayart, Design of Intelligent Distributed Control Systems: A Dependability Point of View, Reliab. Eng. Syst. Safe. 84 (1) (2004) 19-32, doi: http://dx.doi.org/10.1016/S0951-8320(03)00174-1.

4. J. C. Campelo, P. Yuste, P. J. Gil, J. J. Serrano, A Real-Time Distributed Industrial Control System for Embedded Applications, Control Eng. Pract. 9 (2001) 439-447, doi: http:// dx.doi.org/10.1016/S0967-0661(00)00120-9.

5. A. Rullán, Programmable Logic Controllers versus Personal Computers for Process Control, Comput. Ind. Eng. 33 (1-2) (1997) 421-424, doi: http://dx.doi.org/10.1016/S03608352(97)00127-7.

6. G. Valencia-Palomo, J. A. Rossiter, Programmable Logic Controller Implementation of an Auto-Tuned Predictive Control Based on Minimal Plant Information, ISA T. 50 (1) (2011) 92100, doi: http://dx.doi.org/10.1016/j.isatra.2010.10.002.

7. W. Bolton, Programmable Logic Controllers 5 (2009) 1-19, doi: http://dx.doi.org/10.1016/B978-1-85617-7511.00001-X.

8. L. Reznik, O. Ghanayem, A. Bourmistrov, PID Plus Fuzzy Controller Structures as a Design Base for Industrial Applications, Eng. Appl. Artif. Intel. 13 (4) (2000) 419-430, doi: http://dx.doi.org/10.1016/S0952-1976(00)00013-0.

9. R. C. Panda, Synthesis of PID Controller for Unstable and Integrating Processes, Chem. Eng. Sci. 64 (12) (2009) 28072816, doi: http://dx.doi.org/10.1016/j.ces.2009.02.051.

10. M. Escobar, J. O. Trierweiler, Multivariable PID Controller
Design for Chemical Processes by Frequency Response Approximation, Chem. Eng. Sci. 88 (2013) 1-15, doi: http:// dx.doi.org/10.1016/j.ces.2012.11.011.

11. H. M. S. Lababidi, S. Kotob, B. Yousuf, Refinery Advanced Process Control Planning System, Comput. Chem. Eng. 26 (9) (2002) 1303-1319, doi: http://dx.doi.org/10.1016/ S0098-1354(02)00096-0.

12. L. Dobos, J. Abonyi, Application of Non-linear Dynamic Optimization in Advanced Process Control of Product Grade Transitions of Polymerization Processes, Comput. Aided Chem. Eng. 28 (2010) 559-564, doi: http://dx.doi. org/10.1016/S1570-7946(10)28094-X.

13. S. Z. Gao, J. S. Wang, X. W. Gao, Modeling and Advanced Control Method of PVC Polymerization Process, J. Process Contr. 23 (2013) 664-681, doi: http://dx.doi.org/10.1016/j. jprocont.2013.02.008.

14. W. Al-Gherwi, H. Budman, A. Elkamel, A Robust Distributed Model Predictive Control Algorithm, J. Process Contr. 21 (8) (2011) 1127-1137, doi: http://dx.doi.org/10.1016/j.jprocont.2011.07.002.

15. A. Willersrud, L. Imsland, S. O. Hauger, P. Kittilsen, Short-term Production Optimization of Offshore Oil and Gas Production Using Nonlinear Model Predictive Control, J. Process Contr. 23 (2) (2013) 215-223, doi: http://dx.doi.org/10.1016/j. jprocont.2012.08.005.

16. F. Malchow, O. Sawodny, Model Based Feedforward Control of an Industrial Glass Feeder, Control Eng. Pract. 20 (1) (2012) 62-68, doi: http://dx.doi.org/10.1016/j.conengprac.2011.09.004.

17. H. Peng, T. Ozaki, Y. Toyoda, H. Shioya, K. Nakano, V. Haggan-Ozaki, M. Mori, RBF-ARX Model-Based Nonlinear System Modeling and Predictive Control with Application to a NOx Decomposition Process, Control Eng. Pract. 12 (4) (2004) 191-203, doi: http://dx.doi.org/10.1016/S09670661(03)00050-9.

18. H. Badreddinea, S. Vandewalleb, J. Meyersa, Sequential Quadratic Programming (SQP) for optimal control in direct numerical simulation of turbulent flow, J. of Comp. Phy. 256 (2014) 1-16, doi: http://dx.doi.org/10.1016/j. jcp.2013.08.044.

19. M. Fesangharya, M. Mahdavi, M. Minary-Jolandanc, Y. Alizadeha, Hybridizing harmony search algorithm with sequential quadratic programming for engineering optimization problems, Comp. Meth. in App. Mech. and Eng. 197 (3340) (2008) 3080-3091, doi: http://dx.doi.org/10.1016/j. cma.2008.02.006.

20. R. Sharmaa, B. Glemmestadb, On Generalized Reduced Gradient method with multi-start and self-optimizing control structure for gas lift allocation optimization, J. Process Contr. 23 (8) (2013) 1129-1140, doi: http://dx.doi.org/10.1016/j. jprocont.2013.07.001.

21. S. Howes, J. LePore, I. Mohler, N. Bolf, Implementing Advanced Process Control for Refineries and Chemical Plants, Goriva i maziva 53 (2) (2014) 297-119

22. J. Buzása, R. Kicsinyb, Transfer functions of solar collectors for dynamical analysis and control design, Renewable Eng. 68 (2014) 146-155, doi: http://dx.doi.org/10.1016/j. renene.2014.01.037.

23. N. D. Ramirez-Beltran, Transfer function models to control a chemical process, Comp. \& Ind. Eng. 33 (1-2) (1997) 417, doi: http://dx.doi.org/10.1016/S0360-8352(97)00126-5.

24. URL: http://www.PiControlSolutions.com (3. 3. 2014.). 


\title{
SAŽETAK
}

\section{Primjena naprednog vođenja i optimiranja regulacije u industrijskim postrojenjima

\author{
Steve Howes, ${ }^{\text {a }}$ van Mohler ${ }^{\text {b* }}$ i Nenad Bolf ${ }^{\text {b }}$
}

\begin{abstract}
U ovome radu opisana je nova praktična metoda i softver za identificiranje sustava, ugađanje parametara regulatora i optimiranje sustava za vođenje procesa. Prikazani pristup i alati omogućuju inženjerima projektiranje i primjenu različitih metoda vođenja procesa unutar DCS-a i PLC-a. Opisanom metodom identificiraju se empirijski modeli regulacijskih krugova na temelju podataka iz postojećih regulacijskih krugova i optimiraju se parametri regulatora. Na temelju određenih dinamičkih i statičkih karakteristika procesa moguće je razviti prilagodljive i napredne metode vođenja. Softverski alati služe za obuku inženjera i operatora, ali i za praktičnu primjenu. Optimiranjem standardne i napredne regulacije stabilizirat će se proces, a postrojenje će raditi bliže procesnim, sigurnosnim i ekonomskim granicama. Na taj način povećava se kapacitet proizvodnje, smanjuju se troškovi energenata i troškovi održavanja, a raste kvaliteta proizvoda.
\end{abstract}

\section{Ključne riječi}

Identificiranje sustava, ugađanje regulatora, napredno vođenje procesa, regulacija poduprijeta modelom procesa, optimiranje

a PiControl Solutions, Houston, TX, SAD

b Fakultet kemijskog inženjerstva $i$ tehnologije Sveučilišta u Zagrebu

Savska c. $16 / 5 a$

10000 Zagreb
Stručni rad Prispjelo 5. ožujka 2014. Prihvaćeno 12. studenoga 2014. 